УДК 342.9(477)

DOI https: / / doi.org/10.32837/yuv.v0i5.2000

\author{
Р. Лемеха, \\ кандидат юридичних наук, \\ здобувач наукового ступеня доктора юридичних наук \\ Запорізького національного університету
}

\title{
СПІВВІДНОШЕННЯ ПРИВАТНОГО ТА ПУБЛІЧНОГО ІНТЕРЕСІВ У ПРОЦЕСІ РЕАЛІЗАЦІЇ МИТНИХ РЕЖИМІВ В УКРАЇНІ
}

Вступ. Українське суспільство розвивається під впливом світових процесів глобалізації та інформатизації. В умовах глобалізованої економіки важливою $€$ раціональна та науково обгрунтована політика держави у сфері митних відносин із метою захисту національного виробника та наповнення національного бюджету. Органи публічної адміністрації повинні чітко та послідовно захищати вказані публічні інтереси української держави, яким часто протистоять приватні інтереси транснаціональних корпорацій і окремих приватних фірм та інвесторів, які зацікавлені у зменшенні податкових (митних) зобов'язань та просуванні власної продукції на український ринок. 3 метою реалізації приватних інтересів суб'єкти зовнішньоекономічної діяльності використовують різні важелі впливу на публічну адміністрацію, зокрема лобіювання внесення змін до чинного законодавства щодо митних режимів та ставок митних платежів. Правові категорії «публічний інтерес» та «приватний інтерес» досить детально досліджені в теорії держави та права, а також у доктрині адміністративного права, адже саме публічні або приватні інтереси (потреби) є основою мотиву будь-якої правової поведінки та визначають зміст і мету правового регулювання. Завданням юридичної науки є пошук оптимального балансу між публічними та приватними інтересами. Так, у процесі реалізації митних режимів публічний інтерес органів публічної адміністрації в особі Державної митної служби України полягає в забезпеченні належного митного оформлення переміщення товарів і транспортних засобів через митний кордон України, професійному виконанні всіх митних формальностей, якісному адмініструванні сплати всіх передбачених чинним законодавством митних платежів у повному обсязі, ефективному здійсненні митного контролю дотримання норм Митного кодексу України й інших законодавчих актів суб'єктами зовнішньоекономічної діяльності. Приватний інтерес останніх полягає в максимально швидкому проходженні всіх митних процедур та мінімізації розміру митних платежів, які підлягають сплаті. Отже, дослідження співвідношення публічного та приватного інтересів у процесі реалізації митних режимів має не тільки теоретичне, але і практичне значення, покликане стати основою для формулювання конкретних пропозицій щодо вдосконалення чинного національного законодавства та юридичної практики у сфері митних відносин.

Дослідженню питань правового регулювання митних відносин присвятили праці такі відомі науковці, як: О. Бандурка, В. Бевзенко, Н. Білак, М. Віхляєв, Н. Губерська, С. Гусаров, I. Іщук, Р. Калюжний, I. Карамбович, Т. Коломоєць, В. Колпаков, С. Коляда, 
А. Комзюк, О. Кузьменко, В. Курило, Д. Лук'янець, Д. Лученко, П. Лютіков, В. Мартинюк, М. Мельник, Р. Мельник, О. Миколенко, А. Мостовий, Я. Назарова, В. Науменко, Н. Нижник, Н. Осадча, П. Пашко, Д. Приймаченко, С. Стеценко, М. Тищенко, О. Чуприна й інші вчені-адміністративісти.

Правові категорії «публічний інтерес» та «приватний інтерес» у доктрині адміністративного права досить детально дослідила Л. Золотухіна у працях «Історія розвитку національного законодавства в контексті реалізації «публічних інтересів»» [1], «Зміст публічного інтересу як адміністративно-правової категорії» [2], «Діалектика співвідношення публічних і приватних інтересів як адміністративно-правових категорій» [3], «Адміністративно-правовий механізм забезпечення реалізації публічного інтересу» [4].

Значну увагу категоріям приватного та публічного інтересів приділяють теоретики держави і права. Так, співвідношення приватних і публічних інтересів у контексті досвіду України дослідила С. Савченко [5]. На увагу заслуговують і наукові публікації I. Жаровської «Публічні та приватні інтереси в механізмі сучасної державної влади» [6], О. Підопригори «Розмежування і взаємодія публічного і приватного права як методологічна проблема вітчизняного правознавства» [7]. Проте співвідношення публічного та приватного інтересів у процесі реалізації митних режимів в Україні ще не було предметом окремого дослідження, що актуалізуе необхідність підготовки даної публікації.

Методологія даного дослідження грунтується на комплексному поєднанні філософських (закони діалектики та метафізики), загальнонаукових (системний та структурно-функціональний методи, прийоми логічного методу, метод порівняння тощо) та спеціально-юридичних методів дослідження (метод юридичної догматики, методологія порівняльного правознавства, метод юридичного моделювання тощо), принципів об'єктивності йа історизму.

Постановка завдання. Метою публікації $€$ дослідження співвідношення публічного та приватного інтересів у процесі реалізації митних режимів в Україні, результатом чого має стати формулювання пропозицій щодо напрямів удосконалення чинного національного законодавства та юридичної практики у сфері митних відносин.

Результати дослідження. Економіка української держави розвивається в умовах жорсткої світової конкуренції, особливо в частині виробництва високотехнологічних товарів із високою доданою вартістю. Україна є аграрною та транзитною державою, проте має чималий потенціал у сфері промисловості, тому для iii економіки важливі створення нових робочих місць, збільшення обсягів експорту товарів та залучення нових інвестицій. Органи публічної адміністрації повинні створювати всі умови для заохочення суб'єктів зовнішньоекономічної діяльності до збільшення кількості та обсягів експортних операцій, адже це є гарантією надходження до України валютної виручки, а також розвитку національного виробництва та зростання національного валового внутрішнього продукту загалом. Дієвим правовим інструментом заохочення суб'єктів підприємницької діяльності до виходу на зовнішні ринки $€$ ефективне правове регулювання митних режимів, які повинні містити чіткі та прогнозовані умови переміщення товарів та транспортних засобів через митний кордон України, сплати передбачених національним законодавством митних платежів, забезпечувати швидке митне оформлення товарів, а також ефективний і прозорий митний контроль дотримання норм Митного кодексу України й інших законодавчих актів. 
У процесі практичної реалізації митних режимів органи публічної адміністрації та суб'єкти зовнішньоекономічної діяльності часто мають різні цілі, керуються різними інтересами. Публічному інтересу органів публічної адміністрації здійснити належне митне оформлення товарів, які переміщуються через митний кордон України, та забезпечити якісний митний контроль дотримання норм митного законодавства іноді протистоїть приватний інтерес суб'єктів зовнішньоекономічної діяльності ухилитися від належного митного оформлення та контролю, а також сплати в повному обсязі всіх митних платежів, занизити митну вартість товарів, які переміщуються через митний кордон України. Варто зазначити, що категорії «приватний інтерес» та «публічний інтерес» досліджуються не тільки в рамках юридичної доктрини. $\mathrm{y}$ нормативно-правових актах національного законодавства містяться нормативні визначення приватного та публічного інтересів.

Так, у ст. 1 Закону України «Про запобігання корупції» від 14 жовтня 2014 р. № 1700-VII «приватний інтерес» визначається як будь-який майновий чи немайновий інтерес особи, зокрема й зумовлений особистими, сімейними, дружніми чи іншими позаслужбовими стосунками з фізичними чи юридичними особами, також тими, що виникають у зв'язку із членством або діяльністю у громадських, політичних, релігійних чи інших організаціях. А реальний конфлікт інтересів визначений як суперечність між приватним інтересом особи та ї̈ службовими чи представницькими повноваженнями, що впливає на об'єктивність або неупередженість ухвалення рішень або на вчинення чи невчинення дій під час виконання зазначених повноважень [8].

Отже, реальний конфлікт інтересів у сфері митних відносин може виникати в разі конфлікту між приватними інтересами суб'єкта владних повноважень та публічними інтересами всього суспільства та держави загалом, які ця особа зобов'язана захищати та реалізовувати за допомогою наданих їй повноважень згідно із чинним законодавством. Наприклад, посадова особа Державної митної служби ухвалює рішення щодо митного оформлення товарів, які переміщуються через митний кордон України із заниженою митною вартістю і належать комерційній структурі іï близького родича.

Непряме визначення публічного (суспільного) інтересу знаходимо в суміжних галузях права. Так, відповідно до ст. 470 Кримінального процесуального кодексу України, прокурор під час вирішення питання про укладення угоди про визнання винуватості зобов'язаний враховувати, зокрема, такі обставини, як: наявність суспільного інтересу в забезпеченні швидкого досудового розслідування і судового провадження, викритті більшої кількості кримінальних правопорушень, а також наявність суспільного інтересу в запобіганні, виявленні чи припиненні більшої кількості кримінальних правопорушень або інших більш тяжких кримінальних правопорушень [9].

Водночас у сучасній доктрині адміністративного права поняття «публічні інтереси» охоплює зміст понять «державні інтереси» та "суспільні інтереси», адже замість поняття «органи державної влади» усе частіше використовується поняття «органи публічної адміністрації». Останнє більшою мірою відповідає європейській концепції публічної влади, яка спирається не на механізм примусу (домінування меншості над більшістю), а на підтримку суспільства, виконує сервісні функціі відповідно до принципу належного урядування. «Публічний» фактично є синонімом «суспільний», адже в перекладі $з$ англійської "public" означає «суспільний». Влада $€$ публічною, тобто такою, що йде від суспільства (згідно 3 Конституцією 
України, носієм суверенітету і єдиним джерелом влади в Україні є народ).

3 огляду на вищезазначене важливим завданням науки адміністративного права $є$ пошук оптимального балансу між публічними та приватними інтересами у процесі реалізації митних режимів в Україні.

Згідно 3 п. 25 ч. 1 ст. 4 Митного кодексу України, митний режим $€$ комплексом взаємопов'язаних правових норм, що відповідно до заявленої мети переміщення товарів через митний кордон України визначають митну процедуру щодо цих товарів, їхній правовий статус, умови оподаткування, зумовлюють їх використання після митного оформлення. Відповідно до п. 21 ч. 1 ст. 4 Митного кодексу України, митна процедура - це зумовлені метою переміщення товарів через митний кордон України сукупність митних формальностей та порядок їх виконання [10].

Митним режимам присвячено розд. V Митного кодексу (далі - MK) України. Так, відповідно до ст. 70 MK України, з метою застосування законодавства України 3 питань митної справи запроваджуються такі митні режими: імпорт (випуск для вільного обігу); реімпорт; експорт (остаточне вивезення); реекспорт; транзит; тимчасове ввезення; тимчасове вивезення; митний склад; вільна митна зона; безмитна торгівля; переробка на митній територіі; переробка за межами митної територіі; знищення або руйнування; відмова на користь держави [10]. Отже, Митний кодекс України встановлює чотирнадцять митних режимів, з яких основними $є$ режими імпорту, експорту та транзиту, адже саме за ними визначаються основні показники зовнішньоекономічної діяльності суб’єктів господарювання та формується загальний торговельний баланс України.

Особливу увагу органи публічної адміністрації повинні приділяти правовим засобам обмеження небажаного для національної економіки імпорту, застосовувати в необхідних випад- ках заходи нетарифного регулювання зовнішньоекономічної діяльності.

Відповідно до п. 13 ч. 1 ст. 4 Митного кодексу України, заходи нетарифного регулювання зовнішньоекономічної діяльності - це не пов'язані із застосуванням мита до товарів, що переміщуються через митний кордон України, встановлені відповідно до закону заборони та/або обмеження, спрямовані на захист внутрішнього ринку, громадського порядку та безпеки, суспільної моралі, на охорону здоров'я та життя людей і тварин, охорону навколишнього природного середовища, захист прав споживачів товарів, що ввозяться в Україну, а також на охорону національної культурної та історичної спадщини [10].

Як відзначають О. Задорожний і А. Ярмак, нетарифні методи регулювання експортно-імпортних операцій є засобом формування зовнішньоекономічної діяльності та за своєю суттю - комплексом заходів обмежувально-заборонного характеру, що застосовуються 3 метою захисту вітчизняних виробників і споживачів, а також проведення ефективної політики в інтересах власної економіки. У загальносвітовій практиці нетарифне регулювання зовнішньоекономічної діяльності здійснюється державою більшою або меншою мірою залежно від економічних, соціальних або політичних завдань, що стоять перед країною, та ситуації у світі [11].

В умовах глобалізації світової економіки значну роль у регулюванні нетарифних інструментів торговельної діяльності відіграє СОТ. Головним принципом СОТ $€$ передбачуваність або відсутність довільного застосування країнами торговельних заходів. Рішення про захист національного ринку повинні ухвалюватися після багатосторонніх консультацій. Цей принцип лежить в основі нетарифного регулювання світової зовнішньоекономічної діяльності. До кількісних та інших обмежень, дозволених у рамках СОT, належать такі: 
- обмеження, що накладаються країнами, які мають проблеми із платіжним балансом;

- обмеження, що накладаються для захисту суспільної моралі, життя чи здоров'я людей, тварин та рослин, для забезпечення дотримання законів чи нормативних актів;

- захисні заходи 3 обмеження імпорту у формі імпортного мита або кількісних обмежень імпорту в разі, коли його збільшення завдає значної шкоди національним виробникам супутньої або конкурентної продукції;

- накладання антидемпінгового мита на відповідну продукцію та компенсаційного мита на субсидовану імпортну продукцію, якщо збільшення такого імпорту завдає значної шкоди національній промисловості;

- технічні бар'єри;

- недискримінаційне застосування кількісних обмежень (ліцензування, квотування) [11].

Згідно з положеннями ст. 197 Митного кодексу України, митницями контролюються документи, які підтверджують дотримання обмежень щодо переміщення товарів через митний кордон України та видаються державними органами або іншими юридичними особами, уповноваженими на їх видачу, якщо подання таких документів органам доходів і зборів передбачено законами України [10].

Отже, органи публічної адміністрації в особі Державної митної служби мають досить потужний інструментарій захисту публічних інтересів української держави.

Крім того, у передбачених Митним кодексом України й іншими законодавчими актами випадках органи публічної адміністрації мають право застосовувати заходи офіційного контролю - фітосанітарний контроль, ветеринарно-санітарний контроль, державний контроль за дотриманням законодавства про харчові продукти, корми, побічні продукти тваринного походження, здоров'я та благополуччя тварин, що проводяться згідно із законодавством України. Отже, з метою реалізації та захисту публічних інтересів можуть застосовуватися вищезазначені правові засоби офіційного контролю, що також покликано захистити національну економіку від імпорту неякісних та шкідливих товарів, стимулювати розвиток відповідного національного виробництва й експорту товарів.

H. Осадча зазначає, що митний режим є дієвим інструментом реалізації митної політики, який являє собою сукупність стимулів та обмежень щодо здійснення зовнішньоекономічної діяльності. Під регуляторним митним режимом, на іi думку, доцільно розуміти велику кількість законів, правил, норм та умов здійснення зовнішньоекономічної діяльності, які обгрунтовують досяжність стратегічних і тактичних цілей певною кількістю суб'єктів, на яких поширюється дія режиму, на підставі принципу балансу стимулу й обмежень із метою мінімізації трансакційних витрат. Регуляторний митний режим являє собою цілеспрямований взаємозв'язок сукупності суб' $є$ ктів економічного процесу в межах інститутів економічної діяльності, ресурсів та стратегій дій щодо реалізації власних економічних інтересів із метою отримання економічних переваг та мінімізації трансакційних витрат. Під час формування кожного митного режиму закладаються обмежувальні та стимулюючі заходи, тобто певні умови, які дозволяють стимулювати деякі корисні для держави види діяльності. Під час формування та використання митного режиму варто виділити два типи інтересів (цілей): інтерес підприємця й інтерес держави. Інтерес держави багатоаспектний та включає захист національних товаровиробників, поліпшення міжнародного становища шляхом ратифікації міжнародних конвенцій та угод, збільшення митних надходжень. Так, суб'єкти державного регулювання зовнішньоекономічної діяльності виконують 
такі основні завдання: забезпечення виконання вимог суб'єктами зовнішньоекономічної діяльності (сплата мита, акцизу, податку на додану вартість, виконання термінових обмежень кожного режиму); захист економічних інтересів національних товаровиробників; дотримання вимог міжнародного права; здійснення індивідуального регулювання зовнішньоекономічної діяльності; налагодження взаємозв'язків із країнами або їх об'єднаннями, які € потенційними покупцями товарів [12].

Цілі підприємців, які займаються зовнішньоекономічною діяльністю, на думку Н. Осадчої, спрямовані на оптимізацію митного оподаткування в напрямі його зменшення, зниження нетарифних бар'єрів, збільшення швидкості митного контролю й оформлення. У раціонально обгрунтованій моделі відносин держави та підприємця $є$ формування такого регуляторного митного режиму, за якого підприємець буде задоволений сприятливими умовами щодо реалізації всіх митних режимів, водночас держава найкращим чином задовольняє свої економічні інтереси. Тобто існує баланс ідеальних відносин між підприємцем та державою, за межами якого як держава, так і підприємець не задовольняють частину свого інтересу. Держава, формуючи свою митну політику, може обстоювати свої економічні інтереси шляхом конструювання відповідних стану економіки митних режимів. Уряд може вводити додаткові зміни до змісту митних режимів, їх склад та механізм використання, вводити нові режими з метою захисту своїх інтересів. Але водночас треба враховувати й інтереси суб'єктів, які в разі збільшення податкового навантаження або введення нових обмежень можуть знаходити нові шляхи оптимізації своєї діяльності, а саме шляхи ухилення від податків або їх зменшення [12].

Загалом варто погодитись із вищевикладеною думкою Н. Осадчої щодо необ- хідності врахування інтересів суб'єктів зовнішньоекономічної діяльності під час внесення змін до змісту митних режимів, адже будь-які правові обмеження чи заборони викликають зворотну реакцію, опір або взагалі відмову суб'єкта від провадження певної діяльності, що може завдати ще більшої шкоди інтересам держави та суспільства.

B. Науменко зазначає, що мета переміщення товарів через митний кордон України обгрунтована в зовнішньоекономічних контрактах, під час вибору митного режиму декларант повинен надати інформацію 3 низки питань: Чи відповідають напрямок та мета переміщення товарів обраному режиму? Чи виконані умови, передбачені для обраного режиму? Чи враховані обмеження, передбачені для митного режиму, під яким перебуває товар? Чи є товари об'єктом митного контролю? Чи виконані в установлених режимах заходи митно-тарифного регулювання та нетарифного регулювання? Чи отриманий у встановленому випадку дозвіл митного органу на застосування даного режиму? Чи сплачені податки та збори згідно з обраним режимом? Чи існують документи, які підтверджують право на застосування обраного режиму [13]?

Механізм реалізації митного режиму, на думку Н. Осадчої, включає певні процедури митного контролю

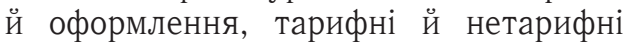
заходи, які можуть бути як стимулюючими, так і обмежувальними, та митний постаудит. Порядок переміщення являє собою комплекс положень, установлених державою для забезпечення фактичного контролю за переміщенням товарів через митний кордон України 3 метою дотримання державних заборон щодо такого переміщення. Тобто порядок установлюється 3 метою дотримання державою своїх економічних інтересів та безпеки життєдіяльності, охорони навколишнього середовища, захисту історичної та культурної спадщини населення, інтелектуальної 
власності й інших інтересів держави. Під час розгляду порядку переміщення товарів необхідно також ураховувати державні обмеження щодо переміщення окремих товарів через митний кордон. Обмеження на ввезення чи вивезення товарів можуть бути встановлені в інтересах економічної політики держави, виконання міжнародних договорів, захисту внутрішнього споживчого ринку. Пропуск таких товарів через митний кордон України можливий на підставі дозвільних документів державних органів, які виконують відповідні контрольні функціі. У межах режимів закладені також певні стимули щодо ввезення чи вивезення товарів, які зумовлені також інтересами держави щодо формування позитивного сальдо платіжного балансу в напрямі стимулювання експорту чи розвитку експортного потенціалу (використання режиму вільної митної зони), глобалізаційними процесами та налагодженням взаємовигідних відносин з іншими краінами [12].

Отже, правове регулювання митних режимів в Україні повинно бути спрямоване на досягнення оптимального балансу між публічними інтересами українського суспільства та держави і приватними інтересами суб'єктів зовнішньоекономічної діяльності, що передбачає створення сприятливих умов для здійснення експорту й імпорту товарів, транзиту, а також реалізації інших митних режимів з урахуванням необхідності захисту інтересів національного виробника, прав українських споживачів на безпечну та якісну продукцію.

Висновки. Проведене дослідження співвідношення публічних та приватних інтересів у процесі реалізації митних режимів в Україні дозволило сформулювати висновок про те, що чинне національне законодавство у сфері правового регулювання митних відносин потребує вдосконалення в напрямі забезпечення оптимального балансу між публічними та приватними інтересами. 3 огляду на нові виклики глобалізації та необхідність захисту національної економіки, створення нових робочих місць та підтримки національного виробника існує необхідність створення додаткових правових стимулів щодо розвитку митних режимів експорту, реекспорту та транзиту, а також переробки на митній території України.

Особливу увагу органи публічної адміністрації повинні приділяти правовим засобам обмеження небажаного для національної економіки імпорту, застосовувати в необхідних випадках заходи нетарифного регулювання зовнішньоекономічної діяльності.

Найбільш ефективними правовими засобами захисту публічних інтересів українського суспільства та держави (захист національної економіки від недобросовісної конкуренції з боку транснаціональних корпорацій, захист інтересів національного виробника тощо) є захисні заходи з обмеження імпорту у формі імпортного мита або кількісних обмежень імпорту в разі, коли його збільшення завдає значної шкоди національним виробникам супутньої або конкурентної продукції; накладання антидемпінгового мита на відповідну продукцію та компенсаційного мита на субсидовану імпортну продукцію, якщо збільшення такого імпорту завдає значної шкоди національній промисловості; недискримінаційне застосування кількісних обмежень (ліцензування, квотування).

Ефективний захист публічних інтересів у процесі реалізаціі митних режимів в Україні є гарантією реалізації приватних інтересів громадян України як кінцевих споживачів товарів, які імпортуються в Україну, щодо безпечного та якісного рівня життя.

Перспектива подальшого наукового аналізу даної тематики зумовлена необхідністю формулювання конкретних пропозицій щодо вдосконалення чинного та формулювання перспективного законодавства України у сфері правового регулювання митних режимів. 
ЮРИАИЧНИЙ ВІСНИК, 2020/5

У науковій публікації досліджуються актуальні питання співвідношення приватного та публічного інтересів у процесі реалізаціі митних режимів в Україні. Зазначається, щз у прощесі реалізащіі митних режимів публічнии інтерес органів публічної адміністрації в особі Державної митної служби України полягає в забезпеченні належного митного оформлення переміщення товарів та транспортних засобів через митний кордон України й ефективному здійсненні митного контролю дотримання норм Митного кодексу України й інших законодавчих актів суб'єктами зовнішньоекономічної діяльності. Водночас зазначеним публічним інтересам часто протистоїть приватний інтерес підприємиів - суб'єктів зовнішньоекономічної діяльності мінімізувати розмір митних платежів або ухилитися від належного митного оформлення та контролю переміщення товарів $і$ транспортних засобів через митний кордон України.

Формулюеться висновок про те, щз чинне національне законодавство у сфері правового регулювання митних відносин потребуе вдосконалення в напрямі забезпечення оптимального балансу між публічними та приватними інтересами. 3 огляду на нові виклики глобалізації та необхідність захисту національної економіки, створення нових робочих місизь та підтримки національного виробника існуе необхідність створення додаткових правових стимулів щодо розвитку митних режимів експорту, реекспорту та транзиту, а також переробки на митній території України. Особливу увагу органи публічної адміністрації повинні приділяти правовим засобам обмеження небажаного для національної економіки імпорту, застосовувати в необхідних випадках заходи нетарифного регулювання зовнішньоекономічної діяльності.
Відзначається, щзо ефективний захист публінних інтересів у процесі реалізації митних режимів в Україні є гарантією реалізацї приватних інтересів громадян України як кінцевих споживачів товарів, які імпортуються в Україну, щуодо безпечного та якісного рівня життя.

Ключові слова: публічний інтерес, приватний інтерес, митне оформлення, митний контроль, митні режими, експорт, імпорт, транзит, правові стимули, захист інтересів, нетарифне регулювання, зовнішньоекономічна діяльність.

Lemekha $R$. The ratio of private and public interests in the implementation of customs regimes in Ukraine

The scientific publication is devoted to the topical issues of the ratio of private and public interests in the implementation of customs regimes in Ukraine. It is noted that in the process of implementation of customs regimes the public interest of public administration bodies represented by the State Customs Service of Ukraine is to ensure proper customs clearance of goods and vehicles across the customs border of Ukraine, professional performance of all customs procedures, quality administration of payment of all customs duties, in full and effective implementation of customs control of compliance with the Customs Code of Ukraine and other legislative acts by subjects of foreign economic activity. At the same time, these public interests are often opposed by the private interest of entrepreneurs to minimize the amount of customs duties or to evade proper customs clearance and control of movement of goods and vehicles across the customs border of Ukraine.

Emphasis is placed on the fact that the legal regulation of customs regimes in Ukraine should be aimed at achieving an optimal balance between 
the public interests of Ukrainian society and the state and private interests of foreign economic activity, which provides favorable conditions for export and import of goods, transit and also the implementation of other customs regimes, taking into account the need to protect the interests of domestic producers, the rights of Ukrainian consumers to safe and quality products.

The conclusion is formulated that the current national legislation in the field of legal regulation of customs relations needs to be improved in the direction of ensuring the optimal balance between public and private interests. Given the new challenges of globalization and the need to protect the national economy, create new jobs and support the national producer, there is a need to create additional legal incentives for the development of customs export, re-export and transit, as well as processing in the customs territory of Ukraine. Public administration bodies should pay special attention to legal means of restricting imports undesirable for the national economy, applying, where necessary, measures of non-tariff regulation of foreign economic activity.

It is noted that the effective protection of public interests in the implementation of customs regimes in Ukraine is a guarantee of the private interests of Ukrainian citizens as final consumers of goods imported into Ukraine, for a safe and quality standard of living.

Key words: public interest, private interest, customs clearance, customs control, customs regimes, export, import, transit, legal incentives, protection of interests, non-tariff regulation, foreign economic activity.

\section{Література}

1. Золотухіна Л. Історія розвитку національного законодавства в контексті реалізаиіі «публічних інтересів». Право $i$ суспільство. 2019. № 3. Ч. 2. С. 41-46.
2. Золотухіна Л. Зміст публічного інтересу як адміністративно-правової категорії. Прикарпатський юридичний вісник. 2017. № 1. T. 2. С. 94-99.

3. Золотухіна Л. Діалектика співвідношення публічних і приватних інтересів як адміністративно-правових категорій. Вісник Запорізького національного університету. Юридичні науки. 2019. № 1. С. $70-77$.

4. Золотухіна Л. Адміністративно-правовии механізм забезпечення реалізації публічного інтересу. Jurnalul juridic national: teorie şi practică. 2019. № 4 (38). C. 61-64.

5. Савченко С. Співвідношення приватних і публінних інтересів: досвід України. Форум права. 2013. № 3. С. 520-527.

6. Жаровська I. Публічні та приватні інтереси у механізмі сучасної державної влади. Науковий вісник Чернівецького університету. Серія "Правознавство». 2010. Bun. 525. C. 33-37.

7. Підопригора О. Розмежування $і$ взаємодія публінного і приватного права як методологічна проблема вітчизняного правознавства. Вісник Академії правових наук України. 2002. №. 4. С. 77-87.

8. Про запобігання корупиіі : Закон України від 14 жовтня 2014 р. № 1700-VII. Дата оновлення: 23.07.2020 p. URL:https: / / zakon.rada.gov.ua/laws/show /1700-18.

9. Кримінальний процесуальний кодекс україни: Закон від 13 квітня 2012 р. № 4651-VI. Дата оновлення: 11.09.2020 p. URL: https: / / zakon.rada.gov.ua/laws / show / 4651-17.

10. Митний кодекс України : Закон віة 13 березня 2012 р. № 4495-VI. Дата оновлення: 19.06.2020. URL: https:// zakon.rada.gov.ua/laws / show / 4495-17 \#Text.

11. Задорожний О., Ярмак А. Нетарифні заходи регулювання зовнішньоекономічної діяльності. Митна справа. 2015. №15 (15).URL:http: / / wrw.visnuk.com.ua / ua/pubs/id/8217.

12. Осадча H. Митні режими та підходи до їх класифікації. Управління економікою: теорія та практика : збірник наукових пращь. Донещьк : IЕП НАНУ, 2009. С. 247-276. URL: http: / / dspace.nbuv.gov.ua/bitstream / handle / 123456789 / 39765 / 16-Osadcha. pdf? sequence $=1$.

13. Науменко В. Применение таможенных режимов в Украине: теория, практика, рекомендации: практическое пособие. Киев, 2005. 430 c. 